\title{
PENGAJIAN AN NAHL DI KAMPUNG PILAHAN, REJOWINANGUN, KOTAGEDE, YOGYAKARTA (1992-2012)
}

\author{
Sidik Fauji \\ IAIN Purwokerto \\ Jl. A. Yani, No. 40 A \\ E-mail: sidikfauji@iainpurwokerto.ac.id
}

\begin{abstract}
The establishment of a study institution in a society is based on the awareness of Muslims about the importance of studying in everyday life. Its existence is very effective as a place and media for learning, especially the religious sciences for mothers, fathers and adolescents. An Nahl recitation in the village of Pilahan was initially formed as well as a forum for learning the religious sciences by mothers. In its development this recitation is not only focused on providing religious materials but is able to create changes to overcome various problems faced by worshipers and the community. One of them is Pengaijian An Nahl providing interest-free loans to the Pilahan community. This research was carried out with the aim of describing the history of the development of the An Nahl Recitation and its contribution to society.

This research is centered on field research. Data or sources used are archives, interviews and research directly at the location of the recitation. The method used in this study is historical research that is used to compile facts, describe, and draw conclusions about the past. The activities carried out in historical methods are topic selection, heuristics, criticism, interpretation and historiography.

The results obtained from this study are descriptions of the An Nahl Study starting from the background established until it developed. In its development the An Nahl Study can be said to have progressed. This can be seen in terms of the number of worshipers who reached hundreds, at first this recitation was only attended by eight people. In terms of quality, there are also better changes. For example, from how to dress, initially some of the pilgrims had not yet worn a veil, after getting the knowledge from Pengajian An Nahl with full awareness they were now wearing it. Besides preaching An Nahl Recitation also provides interest-free debts and scholarships for Pilahan residents who are still in elementary school to high school.
\end{abstract}

Keywords: An Nahl Study, Development, Contributions.

Abstrak: Didirikannya sebuah lembaga pengajian dalam suatu masyarakat tidak lain didasari oleh sebuah kesadaran umat Islam tentang betapa pentingnya menuntut ilmu dalam kehidupan seharihari. Keberadaannya sangat efektif sebagai tempat dan media pembelajaran, khususnya ilmu-ilmu agama bagi kaum ibu, bapak, maupun remaja. Pengajian An Nahl yang berada di kampung Pilahan awalnya terbentuk juga sebagai wadah untuk pembelajaran ilmu-ilmu agama oleh kaum ibu-ibu. Dalam perkembangannya pengajian ini tidak hanya difokuskan pada pemberian materimateri keagamaan tetapi mampu menciptakan perubahan- prubahan untuk mengatasi berbagai permasalahan yang dihadapi oleh jamaah maupun masyarakat. Salah satunya yaitu Pengajian An Nahl memberikan pinjaman tanpa bunga bagi masyarakat Pilahan. Penelitian ini dilaksanakan dengan tujuan untuk mendeskripsikan sejarah perkembangan Pengajian An Nahl serta kontribusinya terhadap masyarakat.

Penelitian ini dipusatkan pada penelitian lapangan. Data atau sumber yang digunakan adalah arsip, hasil wawancara serta penelitian langsung di lokasi tempat pengajian. Metode yang digunakan dalam penelitian ini adalah penelitian sejarah yang dipakai untuk menyusun fakta, mendeskripsikan, dan menarik kesimpulan tentang masa lampau. Adapun kegiatan yang dilakukan dalam metode sejarah yaitu pemilihan topik, heuristik, kritik, interpretasi dan historiografi.

Hasil yang diperoleh dari penelitian ini adalah deskripsi tentang Pengajian An Nahl mulai dari latar belakang didirikan hingga mengalami perkembangan. Dalam perkembangannya Pengajian 
An Nahl dapat dikatakan mengalami kemajuan. Hal ini dapat dilihat dari segi jumlah jamaah yang mencapai ratusan, pada awalnya pengajian ini hanya diikuti oleh delapan orang. Dari segi kualitas juga mengalami perubahan yang lebih baik. Contohnya dari cara berpakaian yang awalnya sebagian jamaah belum memakai kerudung, setelah mendapat ilmu dari Pengajian An Nahl dengan penuh kesadaran sekarang mereka mengenakannya. Selain dakwah Pengajian An Nahl juga memberikan hutang- piutang tanpa bunga dan beasiswa bagi warga Pilahan yang masih duduk di bangku SD sampai SMA.

Kata kunci : Pengajian An Nahl, Perkembangan, Kontribusi

\section{Pendahuluan}

Sejak tahun 1980-an perkembangan lembaga-lembaga pendidikan Islam yang berada di luar sekolah yaitu pendidikan yang dikelola oleh masyarakat tampak cukup pesat, terutama di kota-kota besar. Fenomena ini ditandai berdirinya Taman Pendidikan al- Qur'an (TPA), Taman Kanak-kanak al-Qur'an (TKA), Madrasah Diniyah serta bentuk-bentuk pengajian keagamaan. ${ }^{1}$ Bentuk-bentuk lembaga tersebut khususnya pengajian, dapat bertahan sampai sekarang dan berakar dalam masyarakat. Hal itu karena lembaga pengajian dikelola oleh dan untuk kepentingan masyarakat.

Dilihat dari sifatnya yang telah melembaga di masyarakat sebagai sarana mendapatkan pengetahuan keislaman maka pengajian dapat dikategorikan sebagai lembaga pendidikan non-formal. ${ }^{2}$ Pengajian tersebut pada dasarnya bertujuan untuk menambah ilmu dan keyakinan agama, yang akan mendorong pengalaman ajaran agama serta sebagai tempat silatuhrahmi. ${ }^{3}$ Selain itu juga mengajak manusia untuk berbuat kebaikan agar selamat dari kehidupan dunia dan akhirat.

Lembaga pengajian berfungsi sebagai bentuk pendidikan Islam yang bersifat non-formal memiliki kekhasan tersendiri. Seperti tidak terikat pada faham serta organisasi keagamaan yang sudah tumbuh dan berkembang. Pengajian diselenggarakan atas dasar kebutuhan untuk memahami Islam diselasela kesibukan bekerja atau sebagai pengisi waktu ibu-ibu rumah tangga dalam belajar agama.

Hal demikian juga terjadi pada Pengajian An Nahl di Kampung Pilahan. Pengajian ini terbentuk dari sekelompok ibu-ibu yang ingin mendalami ajaran Islam disela-sela waktu luangnya sebagai ibu rumah tangga. Pengajian An Nahl mulai melangkah pada tahun 1992 yang mula- mula hanya diikuti oleh delapan orang dan bertempat di kediaman Ibu Suparmiatuningsih yang pada saat itu sebagai perintis berdirinya pengajian ini di daerah Pogung Baru. ${ }^{4}$ Karena jumlah jamaahnya semakin meningkat, pada tahun 1994 pengajian ini pindah ke rumah Ibu Bintarto di Sekip, Blok L No. 3. Pada tahun 2000 pengajian ini kemudian mendirikan gedung yayasan sebagai pusat pengajian, tepatnya di Kampung Pilahan, Kelurahan Rejowinangun, Kotagede, Yogyakarta. Yayasan tersebut bernama An Nahl, dari nama yayasan itu kemudian melekat dipengajian ini hingga namanya dikenal dengan Pengajian An Nahl. An Nahl yang berarti lebah adalah makhluk Allah SWT. yang banyak memberi manfaat dan kenikmatan kepada manusia. Dengan pemberian nama ini diharapkan Pengajian An Nahl dapat memberikan halhal positif serta membawa perubahan bagi masyarakat.

Kelompok pengajian saat ini bisa dikatakan sangat banyak, baik di kampung maupun kota, di masjid-masjid atau pun di rumah-rumah warga, bahkan dengan kemajuan teknologi dan informasi, sekarang pengajian dengan mudah dapat kita ikuti melalui saluran 
televisi atau radio tanpa menghadiri sebuah majlis. Selain Pengajian An Nahl, di Kampung Pilahan ada beberapa kelompok pengajian yang penulis ketahui. Pertama, pengajian bapak-bapak yang dilaksanakan dua minggu sekali yaitu setiap malam Rabu. Selain itu juga ada pengajian bulanan yang dilaksanakan setiap Jumat Pon. Kedua, pengajian ibuibu yang dilaksanakan setiap dua minggu sekali pada malam Rabu (jika malam Rabu pertama pengajian bapak-bapak, maka malam Rabu selanjutnya pengajian ibuibu, kemudian pengajian bapak-bapak lagi dan seterusnya secara bergantian tiap minggunya). Sedangkan untuk pengajian bulanan ibu-ibu dilaksanakan setiap Jumat Kliwon. Ketiga, pengajian remaja yang dilaksanakan setiap malam Sabtu. Keempat, pengajian umum, yaitu pengajian warga Pilahan baik bapakbapak, ibu-ibu maupun remaja menjadi satu. ${ }^{5}$

Ada beberapa hal yang membedakan Pengajian An Nahl dengan pengajian yang ada di Kampung Pilahan. Pertama, Pengajian An Nahl mempunyai kepedulian yang besar terhadap desa-desa di berbagai daerah untuk dibinanya. Hal ini dibuktikan dengan mengirimkan ustadz setiap Minggunya ke daerahdaerah untuk mengadakan pengajian. Setidaknya ada enam daerah binaan di tempat yang berbeda, yakni Tepus dan Desa Kamal di Gunungkidul, Kalibawang di Kulonprogo, Kentingan di Solo, dan Munggur serta Menteseh di Karanganyar. Di daerah tersebut pada saat itu masih sangat minim aktifitas keagamaan. Selain mengirimkan ustadz untuk mengisi pengajian, Pengajian An Nahl juga memberikan beasiswa kepada anak-anak di daerah yang dibinanya. Kedua, Pengajian An Nahl memberikan hutangpiutang tanpa bunga bagi masyarakat Pilahan, disamping itu juga memberikan beasiswa bagi warga Pilahan yang masih duduk di bangku SD sampai SMA.
Dibandingkan dengan pengajian lain yang ada di Pilahan, Pengajian An Nahl memberikan kontribusi lebih besar terhadap masyarakat. Ketiga, setiap tiga bulan sekali, Pengajian An Nahl mengadakan mabit yang tujuan utamanya untuk memberi bekal jamaahnya agar memiliki jiwa kewirausahaan. Dengan demikian jamaah diharapkan mampu mengembangkan potensi yang ada pada dirinya. Dari beberapa perbedaan tersebut dapat disimpulkan bahwa Pengajian An Nahl mencoba untuk memberikan perubahan terhadap kegiatan pengajian, minimal agar pengajian seimbang dengan pembahasan problematika kehidupan. Hal ini yang menyebabkan penulis tertarik untuk mengkaji lebih dalam lagi tentang Pengajian An Nahl.

\section{Pembahasan}

\section{A. Sejarah Berdiri Pengajian an Nahl}

Pengajian an Nahl yang dijadikan sebagai objek dalam penulisan ini awalnya hanyalah sekumpulan ibu-ibu yang ingin mengkaji Islam lebih dalam lagi diselasela waktunya sebagai ibu rumah tangga. Dilaksanakan pertama kali pada tahun 1992 di rumah Ibu Suparmiatuningsih, perintis berdirinya Pengajian an Nahl, di daerah Pogung Baru. Di ruang tamu kediamannya menjadi saksi bisu atas terselenggaranya pengajian ini.

Salah satu persoalan yang menjadi perhatian Ibu Suparmiatuningsih saat itu adalah tentang pakaian wanita Muslim. Dia mengatakan, "pada saat itu banyak wanita yang berpakaian berleher rendah hingga dadanya tampak, bahkan ada yang menampakkan belahan dadanya". 6 Padahal pakaian yang sempit dan ketat hingga garis tubuhnya tampak dengan jelas inilah yang merendahkan martabat kewanitaan mereka.

$\begin{array}{ccc}\text { Dalam agama Islam, tidak } \\ \text { dibenarkan hal demikian, } & \text { Islam }\end{array}$


mengajarkan agar kaum wanita menjaga martabatnya dengan sebaik-baiknya, salah satu cara yaitu dengan berpakaian sebaik mungkin, misalnya dengan memakai kerudung. Bukan bahan pakaian yang menentukan martabat seseorang, tetapi cara berpakaianlah yang memegang peranan. Pakaian juga akan membedakan wanita Muslim dengan lainnya, yaitu mempertegas eksistensi wanita Muslim di masyarakat.

Melihat keadaan yang demikian maka Ibu Suparmiatuningsih merasa terketuk hatinya untuk mencoba mengajak teman-temannya supaya mengkaji, mendalami serta sekaligus ingin mendapatkan pengalaman keagamaan. Meskipun usia remaja yang sebagian besar tidak memakai kerudung, tetapi Ibu Suparmiatuningsih lebih memilih ibu-ibu untuk diajak bersama-sama mengkaji permasalahan yang ada. Hal itu dikarenakan dia mempunyai keyakinan bahwa masyarakat yang bagus dimulai dari rumah tangga, yaitu peran ibu yang sangat berarti. Dia mengatakan:

“Dalam sebuah kehidupan bermasyarakat yang baik dimulai dari rumah tangga, yaitu peran orang tua, ibu khususnya. Memberikan contoh teladan yang baik dari para orang tua kepada anak-anaknya adalah merupakan salah satu dari sekian banyak tanggung jawab orang tua pada sang anak. Jika ibunya baik insya Allah anaknya baik, dengan demikian diharapkan akan melahirkan generasi yang baik juga." 7

Ibu Suparmiatuningsih menyadari bahwa dirinya belum cukup ilmu untuk meluruskan permasalahan yang ada di masyarakat saat itu. Masalah lain juga dating yaitu rasa keingin tahuannya tentang bagaimana hokum praktik-praktik keagamaan yang ada di masyarakat, khususnya tentang amalan-amalan apakah itu termasuk bid'ah atau tidak.
Oleh karenanya dia mempunyai rencana untuk mengadakan pengajian di rumahnya dengan menghadirkan seorang ustadz. Dia berharap dengan mengadakan pengajian akan banyak materi yang didapat tentang ajaran agama. Dengan demikian akan membawa perubahan yang lebih baik dalam kehidupan bermasyarakat.

Niat yang mulia dari Ibu Suparmiatuningsih untuk menyelenggarakan pengajian pada saat itu belum terlaksana. Kesibukannya sebagai bussines woman sulit membagi waktu serta mengajak teman-temannya untuk mengadakan pengajian. Di samping itu juga dia akan menunaikan ibadah umroh. Selain materi tentunya persiapan fisik sangat penting dan butuh waktu yang cukup lama untuk mempersiapkan semuanya. Ibu Suparmiatuningsih tidak lupa berdoa saat di baitullah agar niatnya untuk menyelenggarakan pengajian dapat terkabul. Dia percaya dengan niatnya yang mulia serta tidak berputus asa, maka akan selalu ada solusi dan jalan keluar di dalam setiap permasalahan yang dihadapi. Dia juga mengatakan, "banyak kunci sukses untuk dipilih. Anda tinggal memilih kunci sukses, karena hidup itu pilihan". 8

Suatu pertemuan yang tidak terencana sebelumnya, setelah melakukan serangkaian ibadah umroh, Ibu Suparmiatuningsih bertemu seseorang yang memberi buku berjudul al Insanul Kamil karya as Sayyid Muhammad Alwy al Malik al Hasani. Ibu Suparmiatuningsih ingin mengkaji lebih dalam lagi tentang buku tersebut, tentunya tidak melupakan niat awalnya yang prihatin dengan kondisi cara berpakaian wanita Muslim saat itu.

Setelah pulang dari baitullah, langkah pertama yang dilakukan oleh Ibu Suparmiatuningsih adalah melakukan pendekatan dengan seorang ustadz 
bernama Fahmi Muqaddas. Kemudian mereka mengadakan dialog dan Ibu Suparmiatuningsih mengutarakan keinginannya untuk mengkaji buku berjudul al Insanul Kamil yang diperolehnya saat melakukan ibadah umroh. Selain itu ustadz Fahmi juga dimintai pendapat dan pemikirannya, diajak menganalisa tentang keadaan permasalahan yang dihadapi masyarakat, tentang berpakaian khususnya, serta tidak lupa Ibu Suparmiatuningsih mengatakan bahwa dia ingin mendirikan pengajian.

Seusai melakukan dialog dengan Ibu Suparmiatuningsih, ustadz Fahmi kemudian berencana mencarikan ustadz yang tepat untuk mengkaji buku al Insanul Kamil tersebut. Akhirnya dia menemui salah seorang rekannya, yaitu salah satu guru dari Madrasah Mu'allimin Mu'allimaat Muhammadiyah Yogyakarta bernama ustadz Sumedi. Perbincangan pendek pun terjadi antara keduanya dan ustadz Sumedi menerima tawaran untuk menjadi ustadz pengajian di rumah Ibu Suparmiatuningsih.

Setelah mengetahui bahwa ustadz Sumedi bersedia mengisi pengajian, maka Ibu Suparmiatuningsih mengajak temantemannya untuk bersama-sama mengaji di rumahnya menurut Ibu Suparmiatuningsih, kalau kita mau mengubah masyarakat maka kita harus mengubah dari yang terdekat dulu, oleh karenanya dia memilih untuk mengajak teman-temannya. Hal tersebut dibenarkan oleh Ibu Jundan, salah satu orang yang dihubungi oleh Ibu Suparmiatuningsih, dia mengatakan, "dulu saya dan temanteman lainnya diajak oleh Ibu Suparmiatuningsih untuk mengadakan pengajian di rumahnya, kami pun bermusyawarah dan menyetujui ajakan tersebut". 9 Pada tahun 1992 berdirilah sebuah kelompok pengajian yang terdiri delapan orang di kediaman Ibu Suparmiatuningsih di daerah Pogung Baru. Kedelapan orang tersebut adalah
Ibu Suparmiatuningsih, Bintarto, Ismudiyanti, Suharyono, Sumarlan, Sa'adah Fahmi, dan Ibu Jundan.

\section{B. Perkembangan Pengajian an Nahl (1992-2012)}

1. Periode I (1992-1993)

Periode I

(1992-1993), merupakan periode awal Pengajian an Nahl. Pada periode ini kegiatan pengajian berlangsung di rumah Ibu Suparmiatuningsih yang beralamat di Pogung Baru, Blok AIV/10. Dilaksanakan seminggu sekali yaitu setiap hari Kamis dari pukul 10.00 WIB sampai waktu Dhuhur. Laju perkembangan pengajian ini pada awal berdirinya belum menunjukkan sesuatu hal yang signifikan. Hal ini dikarenakan keberadaan pengajian belum dikenal oleh masyarakat di luar daerah Pogung. Pada saat itu jamaah baru berjumlah delapan orang, tetapi keberadaan pengajian tersebut telah dapat dirasakan oleh para jamaah, mereka setidaknya tidak terlalu buta tentang pengetahuan ajaran-ajaran Islam.

Pembahasan materi pada saat itu difokuskan pada pengkajian buku al Insanul Kamil karya as Sayyid Muhammad bin al Maliki al Hasani. Buku ini menguraikan panjang lebar dan terperinci tentang keteladanan seorang Rasul di berbagai aspek kehidupan baik dalam bidang pendidikan, religi, bahkan sosial politik. ${ }^{10}$ Selain penyampaian materi dari buku tersebut, pada periode ini juga belum ada kepengurusan pengajian. Oleh karena itu, jika akan melakukan sesuatu kegiatan terlebih dahulu dilakukan musyawarah dan kemudian dilakukan pembagian tugas. 
Pada periode I ini progam pengembangan wilayah belum ada karena kegiatannya masih disesuaikan dengan kondisi saat itu salah satunya yaitu untuk memenuhi kebutuhan pengajian seperti al Qur'an. Al Qur'an tersebut kemudian digunakan jamaah untuk tadarus bersama dan pada saat itu beberapa jamaah belum lancer membaca al Qur'an. Setelah berjalan satu tahun, seiring juga kesibukan Ibu Suparmiatuningsih yang sering ke Jakarta untuk keperluan pribadinya maka pengajian ini mengalami kendala tempat dalam pelaksanannya. Hal tersebut dikarenakantempat untuk pengajian ini masih menumpang, dalam artian belum mempunyai suatu tempat tersendiri sebagai pusat pelaksanaan kegiatan pengajian.

2. Periode II (1994-1999)

Pada periode II tahun 19941999, pusat pengajian berada di rumah Ibu Bintarto di Sekip Blok L/3. Periode ini mengalami kemajuan yang cukup baik yang ditandai dengan bertambahnya jamaah hingga mencapai tiga puluhan. Adapun jamaah yang dating tidak hanya teman-teman dekat dari Ibu Suparmiatuningsih, tetapi sudah menyebar ke berbagai daerah luar lainnya. Perkembangan yang baik ini dikarenakan keberadaan Pengajian an Nahl dengan segala aktifitasnya mulai dikenal oleh masyarakat luas.

Dengan meningkatnya jumlah jamaah yang dating maka pada periode ini frekuensi pengajian pun ditambah, jika awalnya hanya pada hari Kamis maka di periode II ini menjadi hari Selasa dan Kamis dengan jam yang sama. Tidak hanya frekuensi pengajian, materi juga lebih berfariasi dengan menambah menerjemah al Qur'an. Sampai periode II ini, kepengurusan sangat sederhana dan tidak terlalu formal. Hanya ada bendahara yang mengurusi dana infak. Infak tersebut digunakan untuk keperluan-keperluan penunjang kemajuan pengajian dan juga untuk kegiatan-kegiatan social Pengajian an Nahl,misalnya pembagian beras kepada masyarakat kurang mampu.

Bertambahnya jamaah dengan latar belakang yang berbeda-beda tentu mempunyai persoalan masing-masing. Hal ini tentu menjadi suatu kendala dari segi kualitas pada periode II ini. Salah satu yang menonjol memakai kerudung sebagai wanita Muslim. Beberapa dari mereka memakai kerudung ketika ke pengajian. ${ }^{11}$ Hal ini tentu menjadi perhatian khusus Pengajian an Nahl untuk meningkatkan jamaahnya dari segi kualitas. Salah satunya yaitu dakwah melalui materi yang disampaikan dan pendekatan terhadap jamaah.

Sebagaimana pada periode I, pada periode II sampai tahun 1999 Pengajian an Nahl belum mempunyai tempat tersendiri sebagai pusat kegiatan. Adapun dari jumlah jamaah serta aktifitas pengajian terus berkembang, oleh karena itu pengajian ini berkeinginan untuk memiliki tempat tersendiri sebagai pusat kegiatan pengajian.

3. Periode III (2000-2012)

Suatu perkembangan pesat yang terjadi pada periode ini yaitu ditandai dengan adanya sebuah yayasan sebagai pusat kegiatan. Yayasan an Nahl sebenarnya 
sudah didirikan sejak tahun 1992 yang bersekretariat di Jalan Sekip Yogyakarta, namun pada saat itu yayasan ini belum disahkan dan didaftarkan kepada pejabat yang berwenang sehingga belum menjadi badan hokum. Pada tahun 2000 kemudian Yayasan an Nahl mendirikan sebuah kantor berlantai dua yang kemudian digunakan sebagai pusat pengajian. Yayasan tersebut beralamat di Pilahan KGI/140, Rejowinangun, Kotagede, Yogyakarta. Dengan adanya beberapa kendala terkait perubahan undang-undang, maka Yayasan an Nahl baru disahkan pada tahun $2010 .{ }^{12}$

Frekuensi pengajian pada periode ini menjadi setiap hari Selasa, Kamis, Ahad pagi serta setiap tanggal Sembilan. Dengan ditambahnya frekuensi pengajian, maka jumlah jamaah juga semakin meningkat. Demikian juga dari segi fasilitas yang dimiliki pengajian, dalam perkembangannya selalu melengkapi dengan sarana dan prasarana yang menunjang pengajian. Pada periode ini juga dilakukan pengembangan wilayah pengajian di berbagai daerah, yaitu di Gunung Kidul, Kulonprogo, Karanganyar dan Solo. Hal itu dilakukan dengan mengirim ustadz dari Pengajian an Nahl ke daerah tersebut tiap minggunya.

Pada periode sebelumnya sebagian jamaah masih ada yang belum mengenakan kerudung dan belum lancer membaca al Qur'an. Pada periode III ini sudah menunjukkan kemajuan dari kedua hal tersebut dan tidak lepas dari peran para ustadz di Pengajian an Nahl. Adapun dilihat dari aktifitas yang dilakukan pada periode ini cukup banyak dan sangat positif. Diantaranya yaitu pemberian beasiswa, beras dan hutang-piutang tanpa bunga bagi warga Pilahan, bakti social pemberian pakaian pantas pakai ke daerah-daerah binaan dan sebagainya. Sedangkan untuk jamaah pengajian sendiri, mulai tahun 2010 Pengajian an Nahl menyelenggarakan mabit guna menambah wawasan dalam hal pengembangan potensi diri masing-masing jamaah.

Kepengurusan pada Pengajian an Nahl sangat sederhana, yaitu terdiri dari pembimbing, ketua pengurus dan bendahara. Pemilihan tersebut juga dilakukan dengan masa yang tidak ditentukan. Ini merupakan suatu hal yang perlu diperbaiki dikedepannya agar Pengajian an Nahl memiliki kepengurusan yang lengkap. Namun demikian, kepengurusan yang sederhana tersebut berjalan dengan baik sesuai fungsinya masing-masing.

Sampai tahun 2012

Pengajian an Nahl berjalan dengan baik, hal ini dikarenakan pembinaan pengajian dilakukan dengan sabra. Ibu Suparmiatuningsih berprinsip bahwa untuk menyampaikan ajaran agama harus dilakukan dengan penuh kesabaran. Di samping itu, bagi para jamaah tidak terikat apa pun dan tidak ada aturan harus hafal bacaan tertentu. Sehingga hal ini memiliki daya Tarik tersendirii bagi mereka yang ingin mengikuti pengajian. Berangkat dari gambaran di atas, perjalanan Pengajian an Nahl dalam kurun waktu relative singkat atau masih muda, bias dikatakan mengalami perkembangan yang cukup pesat. 


\section{Peran Pengajian an Nahl terhadap Masyarakat}

1. Memberikan Hutang-Piutang tanpa Bunga

Islam memandang

kesejahteraan social dan individu harus saling melengkapi, bukan untuk bersaing dan berlomba demi kebaikan diri sendiri, melainkan dorongan kerjasama dalam mengembangkan hubungan antar perorangan. Ada banyak cara yang dapat dilakukan seseorang untuk memberikan bantuan kepada orang yang membutuhkan, di antaranya adalah memberikan pinjaman atau hutang-piutang. Hutang-piutang adalah persetujuan pinjam-meminjam uang antara dua belah pihak, di mana satu pihak tersebut berpiutang menyerahkan sejumlah uang (tunai) kepada pihak lain disebut berhutang yang berjanji akan membayar kembali uang tersebut dengan jumlah dan nilai yang sama. ${ }^{13}$

Masyarakat Pilahan telah melakukan praktik hutang-piutang sudah berlangsung sejak lama, mereka melakukan kegiatan ini untuk mencukupi berbagai kebutuhan, salah satunya yaitu bahan makanan. Hutang-piutang di sini merupakan salah satu bentuk kegiatan ekonomi, karena dari hutang-piutang inilah mereka mendapatkan uang untuk mencukupi kebutuhan hidup dan sebagai modal untuk menjalankan usaha mereka. Salah satu warga Pilahan, Ibu Suhartini mengatakan:

"Warga sini (Pilahan) banyak yang melakukan hutang-piutang dari dulu. Terutama saat membutuhkan uang di saat kebutuhan mendesak. Hutang tersebut biasanya digunakan untuk memenuhi kebutuhan da nada juga yang untuk usaha. Tetapi kalau hutang di bank ada bunganya, mengembalikannya harus lebih. Itu yang menjadikan beban."14

Dalam situasi dan kondisi di atas, dalam rangka memberikan peran serta fungsinya, Pengajian an Nahl memberikan hutang-piutang tanpa bunga terhadap masyarakat. Jika jamaah meminjam uang sebesar Rp. 200.000,00 maka dia harus mengembalikan dengan jumlah yang sama. Proses hutangpiutang tersebut berlangsung satu bulan sekali yaitu saat jamaah selesai mengikuti pengajian setiap tanggal Sembilan. Bagi jamaah yang akan berhutang maka setelah pengajian tidak langsung pulang, tetapi menemui pengurus. Besarnya pinjaman yang diberikan tergantung kebutuhan jamaahnya. Adapun sumber dana yang dipinjamkan oleh pengurus tidak berasal dari uang pribadi, melainkan kumpulan dari dana infak setiap Pengajian an Nahl (hari Selasa, Kamis, Ahad pagi dan tanggal sembilan).

Teori Struktur Fungsional yang dikemukakan oleh Emile Durkheim, yaitu bahwa masyarakat sebagai suatu organisasi besar tersusun dari bagian-bagian yang memiliki kedudukan, peranan serta fungsi masing-masing. Komponen itu saling berhubungan dalam mewujudkan sistem sosial. Sistem sosial terjadi karena antara fungsi serta peran saling berhubungan satu sama lain, saling berpengaruhmempengaruhi, saling melengkapi dan secara keseluruhan bersamasama menentukan kkehidupan eksistensi dari masyarakat tersebut sebagai sistem sosial. 
Dapat dipahami bahwa bagian yang saling berhubungan tersebut tersusun dalam bentuk struktur yang masing-masing saling memerankan fungsinya, juga memberikan support pada fungsi dari $b$ agian yang lain, sehingga keseluruhan dalam sistem kehidupan. Adanya sinergi itu menjadikan masyarakat harmonis dan dinamis.

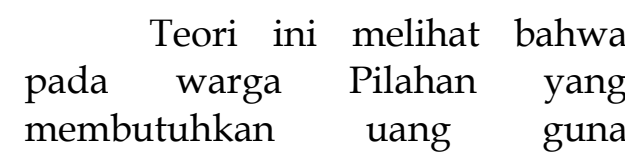
memenuhi kebutuhan hidupnya. Mereka yang mempunyai kebutuhan mendesak terpaksa mengambil langkah dengan cara berhutang. Jika berhutang di bank tentunya akan ada bunga dalam pengembaliannya. Hal tersebut tentu akan menambahkan beban bagi yang meminjamnya. Dalam situasi seperti ini Pengajian an Nahl dalam usaha untuk mencari jalan keluarnya dengan cara memberikan hutang tanpa bunga terhadap masyarakat Pilahan.

2. Pemberian Beasiswa

Pendidikan pada umumnya berarti daya upaya untuk memajukan budi pekerti (kekuatan batin), pikiran (intelek) dan jasmani anak-anak yang selaras dengan alam dan masyarakatnya. ${ }^{15}$ Selain mempunyai tujuan keilmuan, pendidikan juga mempunyai tujuan untuk menjadikan manusia sebagai khalifah yang dapat menjalankan tugasnya dengan baik. Oleh karena pentingnya pendidikan bagi anak sebagai generasi penerus bangsa, maka untuk menunjang sarana pendidikan, Pengajian an Nahl memberikan beasiswa terhadap para siswa warga Pilahan.
Pemberian beasiswa diberikan kepada warga Pilahan yang masih duduk di bangku SD sampai SMA dan mengikuti Pengajian an Nahl. Sampai tahun 2012, ada sekitar tiga puluh siswa yang mendapatkan beasiswa. Besarnya uang yang diberikan yaitu Rp 15.000,00 untuk SD, Rp 20.000,00 untuk SMP dan Rp 25.000,00 untuk SMA. Beasiswa tersebut diberikan sebulan sekali, tepatnya pada minggu kedua setelah mengikuti pengajian Ahad pagi. Setelah pengajian selesai, kemudian anak-anak yang mendapatkan beasiswa pindah ke masjid untuk menerima beasiswa tersebut. ${ }^{16}$ Dengan pemberian beasiswa tersebut diharapkan dapat menggugah atau memotivasi semangat belajar untuk lebih sungguh-sungguh di dalam menuntut ilmu. Adapun sumber dana dihasilkan dari kumpulan infak Pengajian an Nahl. Dalam pemberian beasiswa ini pihak pengajian belum bekerja sama dengan instansi-instansi yang erat kaitannya dengan pendidikan maupun yayasan lain yang sekiranya dapat membantu pemberian beasiswa ini. ${ }^{17}$

Hal ini menandakan bahwa Pengajian an Nahl telah mencoba memberikan kontribusinya bagi para jamaah atau masyarakat sekitar dalam rangka memberi motivasi dan semangat. Secara langsung maupun tidak langsung beasiswa ini memberikan manfaat dan dampak positif bagi anakanak.

3. Pembagian Beras

Agama Islam merupakan agama yang sempurna, dari hal yang besar ke hal yang kecil sekalipun dibahas dalam agama Islam, diantaranya anjuran untuk menolong sesama. Sebagaimana 
diketahui di muka, bahwa masyarakat Pilahan masih banyak yang berpenghasilan menegah ke bawah. Oleh karena itu, salah satu upaya yang dilakukan Pengajian an Nahl dalam rangka meningkatkan kesejahteraan masyarakat sekitarnya yaitu dengan cara pembagian beras. Hal itu dikarenakan beras sebagai makanan pokok dan tentunya selalu menjadi kebutuhan setiap hari.

Beras tersebut diperoleh dari uang infak pengajian hari Selasa Kamis. Dalam pengelolaannya, beras dibagi rata oleh pengurus pengajian dan selanjutnya dibagikan ke warga Pilahan yang mengaji tanggal sembilan.

Bagi Durkheim, nilai-nilai moral adalah dasar dari aturan/tatanan sosial (social order). Dia yakin bahwa adalah menjadi tugas dan tanggung jawab pendidikan, agar anak didik memilih nilai-nilai moral agar mereka menjadi warga masyarakat yang bertanggung jawab dalam arti bahwa sikap dan perilakunya dapat dipertanggungjawabkan.

Teori ini melihat bahwa Pengajian an Nahl, sebagai lembaga pendidikan non-formal yang menanamkan nilai-nilai moral pada jamaahnya dengan cara berbagi dan peduli sesama. Hal tersebut dibuktikan dengan kontribusinya dalam bidang sosial yang meliputi pemberian beasiswa dan pemberian beras kepada masyarakat.

\section{Kesimpulan}

Pengajian An Nahl merupakan salah satu dari beberapa kelompok pengajian yang ada di kampung Pilahan, Rejowinangun, Yogyakarta. Sebelum pusat kegiatan pengajian berada di Pilahan, kelompok pengajian ini berada di rumah Ibu Suparmiatuningsih, perintis berdirinya Pengajian An Nahl, yang beralamat di Pogung Baru Blok A-IV/10. Berdirinya Pengajian An Nahl dilatarbelakangi oleh keprihatinan Ibu Suparmiatuningsih atas keadaan masyarakat saat itu khususnya wanita yang kurang memperhatikan cara berpakaiannya sebagai wanita muslim. Salah satu langkah yang diambil oleh Ibu Suparmiatuningsih atas permasalahan tersebut yaitu dengan mengadakan pengajian di rumahnya. Dia percaya bahwa dengan adanya pengajian maka akan mendapatkan banyak materi yang sesuai untuk diaplikasikan dalam kehidupan seharihari baik di keluarga maupun di masyarakat.

Setelah melalui beberapa persiapan dan proses yang cukup panjang, pada tahun 1992 berdirilah Pengajian An Nahl di rumah Ibu Suparmiatuningsih yang pada saat itu diikuti oleh delapan jamaah ibu-ibu. Nama An Nahl sendiri diambil dari sebuah yayasan bernama An Nahl yang kemudian melekat pada pengajian ini. Pada tahun 1994, pusat kegiatan pengajian ini berpindah di rumah Ibu Bintarto yang beralamat di Sekip Blok L, No. 3. Sampai tahun 1999 pengajian ini masih berada di rumah Ibu Bintarto, hal ini menunjukkan bahwa pengajian ini belum mempunyai tempat sendiri sebagai pusat pengajian. Oleh karena itu pengurus pengajian berkeinginan mendirikan gedung sendiri sebagai pusat kegiatan pengajian. Pada tahun 2000 berdirilah gedung Yayasan An Nahl di Pilahan yang kemudian dijadikan sebagai pusat kegiatan pengajian. Dalam perkembangannya Pengajian An Nahl dapat dikatakan mengalami peningkatan, baik dari jumlah jamaah, kretifitas pengajian dan tentu juga dari segi kualitas jamaah. Di 
balik peningkatan tersebut tentu ada beberapa faktor yang mempengaruhi, baik faktor pendukung maupun penghambat, baik faktor interen maupun eksteren.

Sebagai lembaga keagamaan, Pengajian An Nahl tidak hanya bergerak dalam bidang dakwah saja. Kepeduliannya terhadap masyarakat dapat dilihat di berbagai aktifitasnya seperti pemberian beasiswa siswa SD sampai SMA dan pemberian beras kepada masyarakat Pilahan. Segala kegiatan yang dilakukan oleh Pengajian An Nahl merupakan salah satu bentuk kepeduliannya terhadap masyarakat. Pengajian ini tidak hanya memahami kondisi jamaah serta meningkatkan pengetahuannya, tetapi juga berperan dalam memberikan solusi atas permasalahan-permasalahan yang dihadapi masyarakat. Misalnya saat masyarakat membutuhkan uang untuk kebutuhan hidupnya maka pengajian ini memberikan hutang tanpa bunga dengan harapan tidak memberatkan yang meminjam. Hal ini menunjukkan bahwa Pengajian An Nahl bersifat fungsional terhadap jamaah dan masyarakat.

\section{Kesimpulan.}

Masjid Keramat Pulau Tengah Kerinci salah satu masjid yang mempunyai peranan penting sebagai media pemersatu umat Islam di Kerinci, ia sebagai pusat pendidikan, dan juga dijadikan pusat perlawanan terhadap Belanda. Semangat lasykar, ulama dan masyarakat Kerinci dalam mengusir Kolonialisme Belanda berakar dari semangat juang keagamaan atau spiritual. Dengan kata lain, masjid Keramat dijadikan tempat ditempahnya semangat juang yang tinggi, tidak takut mati, rela berkorban demi agama Allah.

Disamping itu, masjid Keramat digunakan sebagai pusat Perlawanan terhadap Kolonialisme Belanda karena dipengaruhi beberapa faktor yaitu: pertama Masjid Keramat merupakan pranata terpenting bagi masyarakat, kedua Masjid Keramat sebagai pemersatu masyarakat Muslim di Pulau Tengah, ketiga Masjid Keramat tempat bermusyawarah dan kegiatan lainnya, keempat Masjid Keramat sebagai pusat pendidikan. Keempat faktor itulah yang mempengaruhi para Ulama dan masyarakat Kerinci menjadikan masjid Keramat Pulau Tengah sebagai basis dan pusat perlawanan terhadap kolonialisme Belanda sehingga perlawanan yang mereka lakukan termasuk salah satu perjuangan terbesar di Kerinci.

\section{Referensi}

${ }^{11}<$ http://suaranewongdeso.blogspot.com/2 013/04/makalah-majelis-talim.html>, diakses pada tanggal 7 April 2014.

2 Muhammad Zein, Metode Pendidikan Agama Islam Pada Lembaga Pendidikan Nonformal (Yogyakarta: Sumbangsih Offest, 1976), hlm. 10.

3 Tutty Alawiyah, Strategi Dakwah di Lingkungan Majlis Taklim (Bandung: Mizan, 1997), hlm. 78.

4 Wawancara dengan Sumedi (ketua Yayasan An Nahl) di Masjid An Nahl, tanggal 4 April 2013.

${ }^{5}$ Wawancara dengan Junaedi (ketua RW

13) di rumahnya, tanggal 21 Maret 2014.

${ }^{6}$ Wawancara dengan Suparmiatuningsih di kediamannya, tanggal 7 April 2014.

${ }^{7}$ Ibid.

${ }^{8}$ Ibid.

${ }^{9}$ Wawancara dengan Jundan di Yayasan an Nahl, tanggal 8 April 2014.

${ }^{10}$ Wawancara dengan Sumedi di Masjid an Nahl, tanggal 4 April 2014.

${ }^{11}$ Wawancara dengan Suparmiatuninggsih di kediamannya, tanggal 8 April 2014.

12 Pengesahan Yayasan an Nahl sebagai badan hokum tepatnya pada tanggal 2 Februari 2010 dengan Akta Notaris Basuki, S.H., nomor 001, tahun 2010 dan selanjutnya yayasan ini didirikan untuk jangka waktu yang tidak ditentukan lamanya.

Hilman Hadi Kusuma, Hukum Perekonomian Adat Indonesia (Bandung: Aditya Bakti, 2001), hlm. 112. 
${ }^{14}$ Wawancara dengan Suhartini (warga Pilahan), tanggal 18 April 2014.

15 Azyumardi Azra, Pendidikan Islam

Tradisi dan Modernisasi menuju Milenium Baru (Jakarta: Logos Wacana Ilmu, 2000), hlm. 4.

${ }^{16}$ Observasi pada tanggal 9 Februari 2014.

${ }^{17}$ Wawancara dengan Sumedi di Masjid an Nahl, tanggal 4 April 2013.

\section{Buku:}

Alawiyah, Tutty. 1997. Strategi Dakwah di Lingkungan Majlis Taklim. Bandung: Mizan.

Azra, Azyumardi. 2000. Pendidikan Islam Tradisi dan Modernisasi menuju Milenium Baru. Jakarta: Logos Wacana Ilmu.

Hadi Kusuma, Hilman. 2001. Hukum Perekonomian Adat Indonesia. Bandung: Aditya Bakti.

Kartodirjo, Sartono. 1993. Pendekatan Ilmu Sosial dalam Metodologi Sejarah. Jakarta: Gramedia Pustaka Utama.

Zein, Muhammad. 1976. Metode Pendidikan Agama Islam Pada Lembaga Pendidikan Non-formal. Yogyakarta: Sumbangsih Offest.

\section{Wawancara:}

Wawancara dengan Jundan di Yayasan an Nahl, tanggal 8 April 2014.

Wawancara dengan Suhartini (warga

Pilahan), tanggal 18 April 2014.

Wawancara dengan Sumedi di Masjid an Nahl, tanggal 4 April 2013.

Wawancara dengan Suparmiatuningsih di kediamannya, tanggal 7 April 2014.

k kepribadian dan kepatuhannya terhadap Islam. Ketika di Pulau Tengah menjadi salah satu pusat pendidikan, maka ulama mempunyai peran penting, dan Masjid Keramat berada di atas lembaga-lembaga lainnya. 